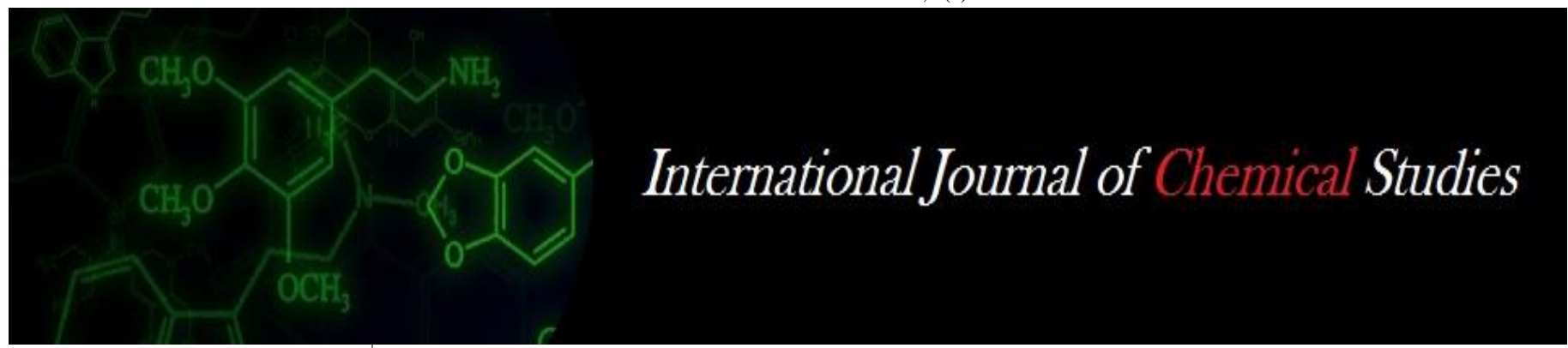

P-ISSN: 2349-8528

E-ISSN: 2321-4902

www.chemijournal.com

IJCS 2020; 8(2): 717-722

(C) 2020 IJCS

Received: 19-01-2020

Accepted: 21-02-2020

Gayari I

Department of Animal Genetics and Breeding, College of

Veterinary Science, AAU, Khanapara, Guwahati, Assam, India

\section{Ferdoci AM}

Department of Animal Genetics and Breeding, College of

Veterinary Science, AAU,

Khanapara, Guwahati, Assam, India

\section{Aziz A}

Department of Animal Genetics and Breeding, College of

Veterinary Science, AAU,

Khanapara, Guwahati, Assam,

India

\section{Zaman GU}

Department of Animal Genetics and Breeding, College of

Veterinary Science, AAU,

Khanapara, Guwahati, Assam, India

\section{Akhtar F}

Department of Animal Genetics and Breeding, College of

Veterinary Science, AAU,

Khanapara, Guwahati, Assam,

India

\section{Deka R}

Department of ARGO, College of Veterinary Science, AAU,

Khanapara, Guwahati, Assam, India

\section{Corresponding Author:}

Gayari I

Department of Animal Genetics and Breeding, College of

Veterinary Science, AAU,

Khanapara, Guwahati, Assam,

India

\section{Prolactin gene polymorphism in crossbred cattle of Assam and its association with productive and reproductive traits}

\author{
Gayari I, Ferdoci AM, Aziz A, Zaman GU, Akhtar F and Deka R
}

DOI: https://doi.org/10.22271/chemi.2020.v8.i2k.8852

\begin{abstract}
The present investigation was designed to study the performance of crossbred cows as well as to identify polymorphism in genomic sequences of PRL gene and its association with various reproductive and productive traits of crossbred cows maintained at the Bull Mother Farm, Barapeta, Assam. A total of 40 cows were utilized to study the polymorphism of the PRL gene, the results of which showed polymorphic banding pattern in most of the samples of crossbred cows with respect to the gene under study. Polymerase Chain Reaction-Restriction Fragment Length Polymorphism studies on PRL gene in crossbred cows, using $R s a$ I restriction enzyme revealed three types of fragment pattern, arbitrarily designated as AA (156 bp), AB (74, 82 and $156 \mathrm{bp}), \mathrm{BB}(74$ and $82 \mathrm{bp}$ ) genotype. The frequencies of A and $\mathrm{B}$ alleles were calculated as 0.534 and 0.466 and those of $\mathrm{AA}, \mathrm{AB}$ and $\mathrm{BB}$ genotypes as $0.334,0.400$ and 0.266 respectively. The prolactin genotypes were found to be significantly related to age at sexual maturity, age at first calving, first lactation milk yield. The crossbred cattle with AB genotype showed better performance than those with AA and BB genotype in the population studied.
\end{abstract}

Keywords: Prolactin gene, crossbred cattle, PCR-RFLP, RSA I

\section{Introduction}

Livestock plays a crucial role in the livelihood of the Indian population. India possesses a rich reservoir of genetic diversity and homes a number of the best bovine breeds. It has 190.9 million bovine out of which 39.73 million are crossbred $\left(19^{\text {th }} \text { Livestock Census, 2012 }\right)^{[5]}$. The cattle breeding policy of Assam, initiated as early as 1980 had set the foundation for improvement of indigenous bovine which included the exotic Jersey and the Indian Red Sindhi breeds of bovine for augmenting milk production. Molecular genetics studies like polymorphism of prolactin gene might be of great help in improving milk production. Keeping in view of these abovementioned facts, the present investigation had been undertaken to study the polymorphism of prolactin gene, estimation of gene and genotype frequencies and association of different genotypes with respect to prolactin gene with the production traits of Jersey $\times$ Red Sindhi crossbred cows maintained at the Bull Mother Farm, Barapeta.

\section{Materials and Methods}

Study area

The data used were collected from the breeding records of Jersey crossbred maintained at Bull Mother Farm, Barapeta, Assam.

\section{Collection and storage of blood}

The present study was conducted at the Core Laboratory, Network Project on Animal Genetic Resources, Department of Animal Genetics and Breeding; Animal Biotechnology and Central Instrumentation Facility (CIF), College of Veterinary Science, Assam Agricultural University, Khanapara, Guwahati-781022. Blood samples were collected from 40 cows. Five ml of blood was aseptically collected from the jugular vein in vacutainer tube containing EDTA $(2.7 \%)$ as anticoagulant. The properly labelled samples were transported in ice packs to the laboratory and were stored in deep freeze at $-20{ }^{\circ} \mathrm{C}$ till the isolation of genomic DNA. 


\section{Reagents and buffers:}

The composition of reagents, buffers and chemicals used in this study are given in Appendix I and Appendix II.

\section{Isolation of genomic DNA}

This procedure was aimed at removal of red blood cells from the whole blood followed by lysis of the WBCs and subsequent liberation of DNA into aqueous phase. DNA was recovered later by addition of alcohol in the presence of monovalent cations.

Genomic DNA was extracted using Phenol Chloroform Extraction Procedure (Sambrook and Russell, 2001) ${ }^{[8]}$ with slight modifications by using DNA zol reagent instead of SDS and proteinase $\mathrm{K}$. The steps involved were as follows:

a) Blood samples were transferred from vacutainers to sterile $15 \mathrm{ml}$ centrifuge tubes.

b) Double volume of RBC lysis buffer was added, mixed well and centrifuged at $7500 \mathrm{rpm}$ for 10 minutes.

c) After centrifugation, the supernatant was discarded and 6-7 ml of RBC lysis buffer was added to the pellet, mixed well and centrifuged at $2500 \mathrm{rpm}$ for 10 minutes.

d) The process was repeated at $1850 \mathrm{rpm}$ until all the RBCs were completely lysed, which was ensured by the formation of white coloured pellet and colourless supernatant after centrifugation.

e) The pellet was resuspended in $750 \mu \mathrm{l}$ DNA zol and equal volume of phenol: chloroform: isoamyl alcohol (25:24:1) mixture was added, vortexed and tubes were centrifuged at $7500 \mathrm{rpm}$ for 10 minutes.

f) The aqueous phase was collected and equal volume of chloroform: isoamyl alcohol (24:1) mixture was added, vortexed and tubes were centrifuged at $7500 \mathrm{rpm}$ for 10 minutes.

g) The supernatant was transferred to an eppendorf tube and 0.6-0.7 volume of isopropanol was added carefully along the wall of the tube.

h) The tubes were gently tilted for DNA to precipitate overnight in $-20^{\circ} \mathrm{C}$.

i) Next day, the DNA was spooled out; $1 \mathrm{ml}$ of $70 \%$ ethanol was added to remove the salts and then centrifuged at $7500 \mathrm{rpm}$ for 10 minutes.

j) The supernatant was discarded, $100 \%$ ethanol was added to the pellet and again centrifuged at $7500 \mathrm{rpm}$ for 10 minutes.

k) Again, the supernatant was removed and the pellet was air dried.

1) $100 \mu \mathrm{l}$ of $\mathrm{TE}$ buffer was added and resuspended by incubating at $65^{\circ} \mathrm{C}$ in water bath for five minutes.

m) The micro centrifuge tube was kept in ice for a while and then stored in $4^{\circ} \mathrm{C}$ for 48 hours for resuspending the DNA completely.

n) The extracted DNA samples were kept in $-20^{\circ} \mathrm{C}$ to avoid degradation until further use.

\section{Quantification and quality assessment of DNA Purity of DNA}

The purity of genomic DNA was assessed by UV spectrophotometer (Nanodrop Spectrophotometer, Model: UV/VIS 916) and Optical Density (OD) values were measured at 260 and $280 \mathrm{~nm}$ with TE buffer as blank, which indicatedthe amount of DNA and the amount of protein, respectively in a given sample. The ratio of OD values at 260 and $280 \mathrm{~nm}$ was used as a criterion to judge the purity. The samples having OD ratio $(260 \mathrm{~nm} / 280 \mathrm{~nm}) 1.7$ to 1.9 were used for the experiment.

\section{Concentration of DNA}

The concentration of genomic DNA was estimated spectrophotometrically by taking OD value at $260 \mathrm{~nm}$. A reading of 1.0 at $260 \mathrm{~nm}$ corresponds to $50 \mu \mathrm{g} / \mathrm{ml}$ of double stranded DNA in the sample. The concentration of DNA was calculated by using the following formula:

DNA concentration $(\mu \mathrm{g} / \mathrm{ml})=$ OD260 $\mathrm{nm} \times$ Dilution factor $\times 50$

\section{Quality of DNA}

Genomic DNA quality was checked to ensure the presence of intact DNA without any shearing. Horizontal submarine agarose gel electrophoresis was performed to check the quality of DNA.

At first, outside edges of the open ends of the plastic gel casting tray was sealed with adhesive tape and placed on a levelling table. The comb at the desired position was fitted on the tray $(0.5-1 \mathrm{~mm}$ above the plate) so that, complete well is formed. Two ml 50X TAE buffer was diluted to $100 \mathrm{ml}$ in a $250 \mathrm{ml}$ Erlenmeyer flask and 1\% Agarose (w/v) was added to the buffer solution. The flask was heated by plugging the neck with aluminium foil in oven for three minutes.

The agarose solution was cooled to $50-55^{\circ} \mathrm{C}$ by swirling occasionally to prevent the agarose from gelling at bottom of the flask and poured into the gel casting tray after adding ethidium bromide solution @ $0.5 \mu \mathrm{g} / \mathrm{ml}$ of gel. The comb and tapes were removed after solidification of gel. The gel casting tray was then submerged in gel tank having $1 \mathrm{X}$ TAE buffer. Five $\mu 1$ of DNA sample was mixed with equal amount of $6 \mathrm{X}$ loading dye and then loaded in the wells. Electrophoresis was carried out at 110 volts for one hour and gel was visualised under gel documentation system (Kodak 100). Quality of the DNA was assessed based on thickness or density of the band appeared. The genomic DNA samples having good quality DNA were used for further analysis.

\section{Template DNA preparation for PCR}

Based on the observed bands in the agarose gel and concentration determined by spectrophotometer the DNA was diluted using TE buffer to obtain the template DNA concentration approximately $100 \mathrm{ng}$ per $\mu \mathrm{l}$ and stored at -20 ${ }^{\circ} \mathrm{C}$ till further use.

\section{PCR for amplifying dna}

The primer sequences were used for PRL gene amplification is presented in the Table 1.

Table 1: Primer for pcr-rflp

\begin{tabular}{|c|c|c|}
\hline Gene & Primer & Reference \\
\hline \multirow{2}{*}{ Rs } & F: 5'-CGAGTCCTTATGAGCTTGATTCTT3' & Vermaet \\
& R:5'-GCCTTCCAGAAGTCGTTTGTTTTC3' & al.(2004) ${ }^{[10]}$ \\
\hline
\end{tabular}

\section{Dilution of primers}

The primers were diluted for working concentration of 10 $\mathrm{pmol} / \mu \mathrm{l}$. Reaction mixture for pcr-rflp (prl gene) is presented in Table 2.

Table 2: Reaction mixture for PCR-RFLP (PRL gene)

\begin{tabular}{|c|c|c|}
\hline PCR components & Volume in $\boldsymbol{\mu l}$ & Final concentration \\
\hline DNA Template & $2 \mu \mathrm{l}$ & $100 \mathrm{ng} / \mu \mathrm{l}$ \\
\hline Forward Primer & $1 \mu 1$ & $10 \mathrm{pmol} / \mu \mathrm{l}$ \\
\hline Reverse Primer & $11 \mu \mathrm{l}$ & $10 \mathrm{pmol} / \mu \mathrm{l}$ \\
\hline Mgcl2 $(25 \mathrm{Mm})$ & $1 \mu 1$ & - \\
\hline Master Mix & $25 \mu 1$ & - \\
\hline Nuclease Free Water & $20 \mu 1$ & - \\
\hline Total & $50 \mu \mathrm{l}$ & - \\
\hline
\end{tabular}


PCR Protocol for amplification of genes is presented in Table 3. Which is followed by agarose gel electrophoresis.

Table 3: PCR protocol for amplification (PRL gene)

\begin{tabular}{|c|c|c|c|}
\hline Step & Process & Temperature & Duration \\
\hline 1 & Initial denaturation & $94^{\circ} \mathrm{C}$ & 2 Minutes \\
\hline 2 & Denaturation & $94^{\circ} \mathrm{C}$ & 1 Minutes \\
\hline 3 & Annealing & $54^{\circ} \mathrm{C}$ & 1 Minutes \\
\hline 4 & Extension & $72^{\circ} \mathrm{C}$ & 30 Seconds \\
\hline 5 & \multicolumn{3}{|c|}{ Repeat steps 2 to 435 cycles } \\
\hline 6 & Final extension & $72^{\circ} \mathrm{C}$ & 10Minutes \\
\hline 7 & Hold & $4{ }^{\circ} \mathrm{C}$ & Until the samples are removed \\
\hline
\end{tabular}

\section{Restriction endonuclease enzyme digestion}

The PCR products $(20 \mu \mathrm{l})$ were digested with restriction enzymes (New England Biolab, UK) as per the manufacturer's protocol. The reaction mixture was vortexed for few seconds for uniform mixing and then incubated at $37^{\circ}$ $\mathrm{C}$ for overnight.

Restriction endonuclease enzymes and their recognition site

\begin{tabular}{|c|c|c|}
\hline Restriction Enzyme & Source & Restriction Site \\
\hline \multirow{2}{*}{ Rsa I } & Rhodopseudomonas sphaeroides & $\begin{array}{l}\text { 5' GT } \downarrow \text { AC 3' } \\
\text { 3’ CA } \uparrow \text { TG 5' }\end{array}$ \\
\hline
\end{tabular}

\section{Analysis of the PCR-RFLP products}

The enzyme digested products were loaded @ $10 \mu \mathrm{l}$ on $2.5 \%$ agarose gel along with $50 \mathrm{bp}$ ladder. Electrophoresis was carried out at $110 \mathrm{~V}$ for 1 hour 15 minutes and the bands were visualized and documented using gel documentation system. The bands were analysed by comparing with the ladder.

\section{Sequencing}

The PCR products were sent for sequencing to first base DNA sequencing division, Malaysia.

\section{Statistical Analysis}

Statistical Analysis were performed as per standard Statistical procedures.

\section{Results}

Amplification of PCR products and visualization of bands The amplification of PCR products were confirmed by $1.5 \%$ agarose gel at $85 \mathrm{~V}$ for 60 minutes along with 100 bp ladder and visualized using gel documentation system (BIO-RAD, USA). PCR products of $156 \mathrm{bp}$ were amplified from PRL gene (Figure 1).

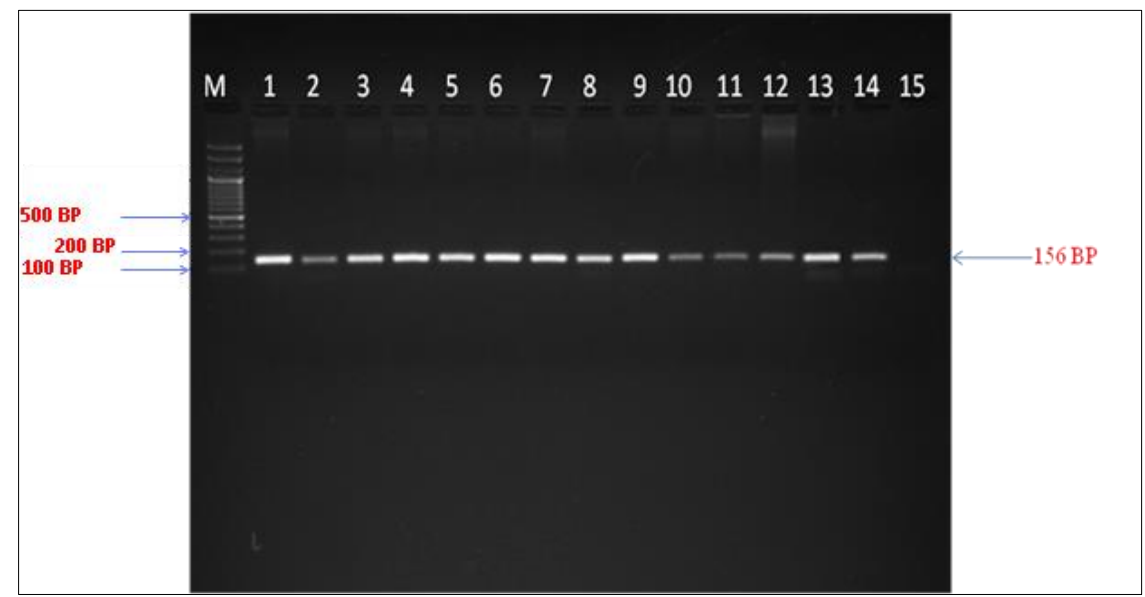

M: 100 bp Marker, L1 -14:PCR products, L 15: Non Template control

Fig 1: PCR amplicon (156 BP) of PRL gene

\section{PCR-RFLP}

Restriction enzyme, viz., Rsa I was used for PCR-RFLP of PRL gene (Figure 2).

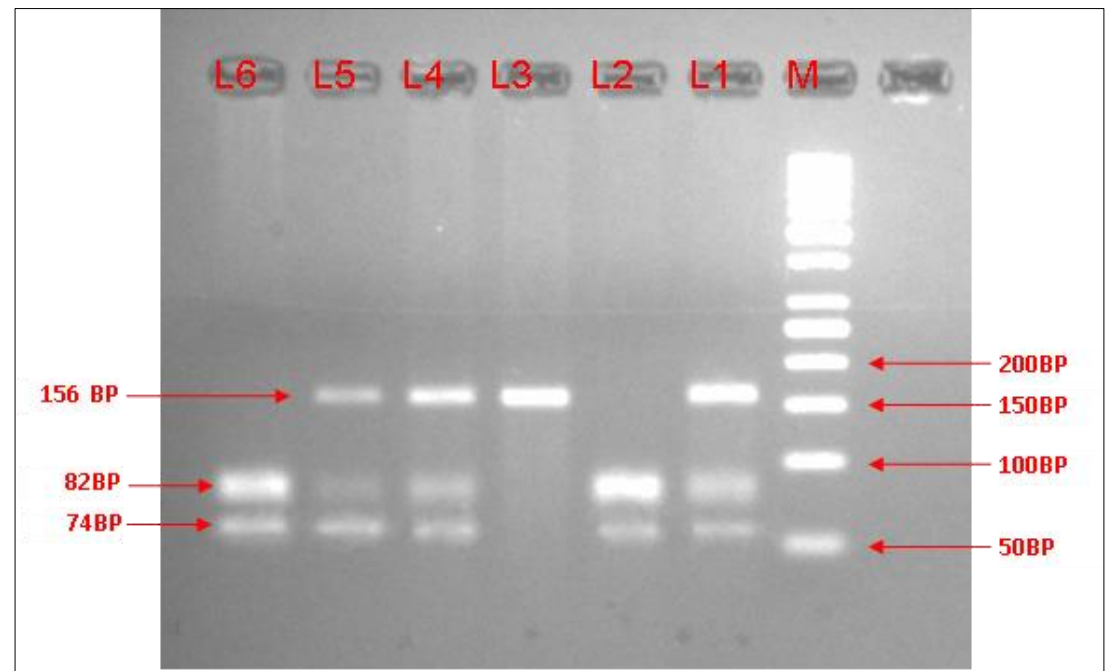

M: 50 bp Marker, L1 - L6: PCR-RFLP products.

Fig 2: PCR-RFLP of PRL gene using RsaI 


\section{PCR-RFLP analysis of PRL gene}

The PCR-RFLP studies on PRL gene in crossbred cow, using Rsa I restriction enzyme revealed three types of fragment pattern, arbitrarily designated as AA, AB, BB genotype. Following digestion of the PCR product, AA genotype yielded one fragment (156 bp), AB genotype yielded three fragments (74, 82 and $156 \mathrm{bp})$ and BB genotype yielded two fragments (74 and $82 \mathrm{bp}$ ) as shown in Figure 2. The frequencies of both the alleles are presented in Table 4.

Table 4: distribution of genotype and allele frequencies of PRL gene along with $\chi^{2}$ value

\begin{tabular}{|c|c|c|c|c|c|}
\hline Genotype & Observed & Expected & Genotype frequency & Allele & Allelic frequency \\
\hline $\mathrm{AA}$ & 10 & 8.748 & 0.334 & A & \multirow{2}{*}{0.534} \\
\hline $\mathrm{AB}$ & 12 & 14.904 & 0.400 & & \\
\hline BB & 8 & 6.348 & 0.266 & B & 0.466 \\
\hline \multicolumn{4}{|c|}{$x^{2}$} & \multicolumn{2}{|r|}{$1.575^{\mathrm{NS}}$} \\
\hline
\end{tabular}

\section{Association of different genotypes with reproduction and production traits}

In the present study, PCR-RFLP technique is used to detect the polymorphism of prolactin gene with $R s a \mathrm{I}$ restriction enzyme for reproduction and production traits of crossbred cattle and the genotype $\mathrm{AB}$ was found to have better performance compared to AA genotype and BB showed the least performance. Association of different genotypes with reproduction and production traits is shown in Table 5.

Table 5: Association of different genotypes with various reproduction and production traits

\begin{tabular}{|c|c|c|c|}
\hline \multirow{2}{*}{ Traits } & \multicolumn{3}{|c|}{ RsaI- RFLP Genotype } \\
\cline { 2 - 4 } & AA & AB & BB \\
\hline Age at Sexual Maturity & $908^{\mathrm{a}} \pm 36.81$ & $868.17^{\mathrm{a}} \pm 11.38$ & $1252.25^{\mathrm{b}} \pm 55.57$ \\
\hline Age at First Calving & $1363.8^{\mathrm{b}} \pm 16.41$ & $1244.5^{\mathrm{a}} \pm 10.32$ & $1661.75^{\mathrm{c}} \pm 13.71$ \\
\hline First Lactation Milk Yield & $1414^{\mathrm{ab}} \pm 27.03$ & $1603.83^{\mathrm{a}} \pm 55.93$ & $1107.25^{\mathrm{b}} \pm 157.89$ \\
\hline First Lactation Length & $278.6 \pm 17.94$ & $312.17 \pm 14.54$ & $262.25 \pm 29.25$ \\
\hline
\end{tabular}

\section{Sequencing}

Sequencing was done using both forward and reverse primers for a few samples representing $\mathrm{AA}, \mathrm{AB}$ and $\mathrm{BB}$ genotypes in PRL gene by automated DNA sequencer (Applied Biosystem, USA) as shown in (Figure 3). The obtained sequences were confirmed by BLAST analysis (Figure 4). Based on scores obtained by BLAST, other nucleotide sequences of PRL gene in Cattle were obtained from NCBI for comparative analysis. Multiple alignment of the sequence was performed using Clustal W as shown in (Figure 5). RsaI restriction site was detected at position 74 of a total 156 bp by partial sequence. The sequence variation in terms of nucleotide was observed in $10,11,12,13,15,25,46,83,129^{\text {th }}$ position.
In the population studied, the groups of crossbred cattle exhibiting polymorphism of PRL gene could be distinguished as $\mathrm{AA}, \mathrm{AB}$ and $\mathrm{BB}$. Notably, there was a greater number of $\mathrm{AB}$ heretozygotes in comparison to $\mathrm{AA}$ and $\mathrm{BB}$ homozygotes. The frequencies of $\mathrm{A}$ and $\mathrm{B}$ alleles were calculated as 0.534 and 0.466 and those of $\mathrm{AA}, \mathrm{AB}$ and $\mathrm{BB}$ genotypes as 0.334 , 0.400 and 0.266 respectively.

The calculated chi-square $\left(\chi^{2}\right)$ value was found to be non significant $(P<0.05)$ and hence indicated that the population under study was in Hardy-Weinberg Equilibrium for PRL gene.

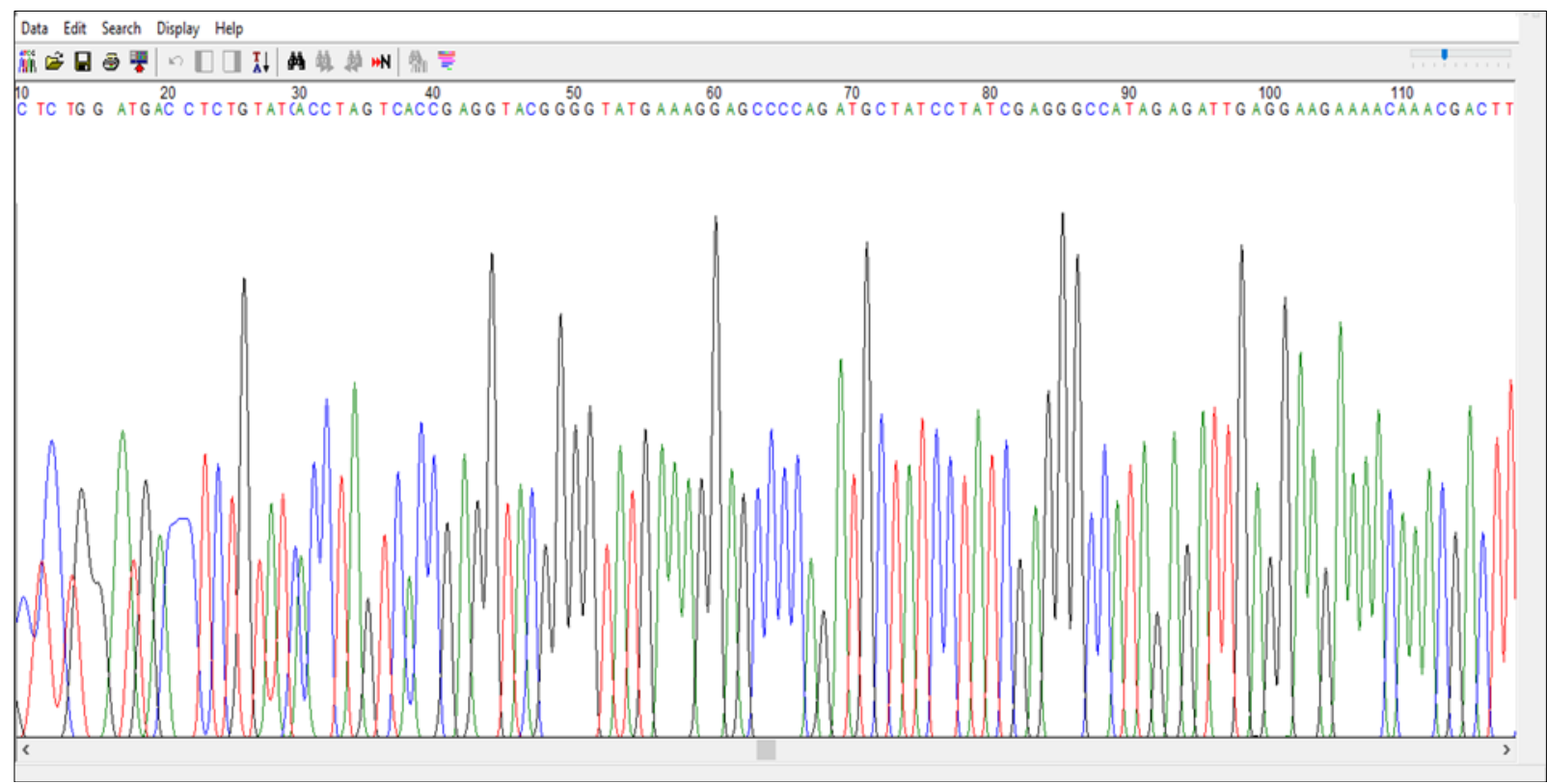

Fig 3: Screenshot of the sequence of PRL gene 


\section{CTCTGGATGACCTCTGTATCACCTAGTCACCGAGGT^ACGGGGTATGAAAGG AGCCCCAGATGCTATCCTATCGAGGGCCATAGAGATTGAGGAAGAAAACAA ACGACTTCTGGAAGGCAA}

Fig 4: Nucleotide sequences alignment of PRL gene

\begin{tabular}{|c|c|c|}
\hline Specieses/Abbrv & Group Nane & 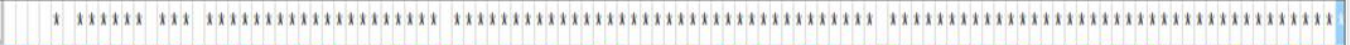 \\
\hline 1. MI__173953_Bos_taurus & & 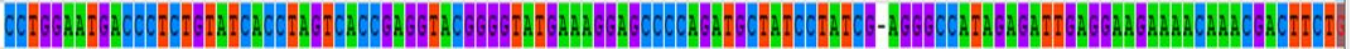 \\
\hline 2. KM7רา612_Sahiwal & & 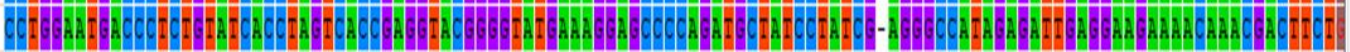 \\
\hline 3. Knרา7614_kankrej & & 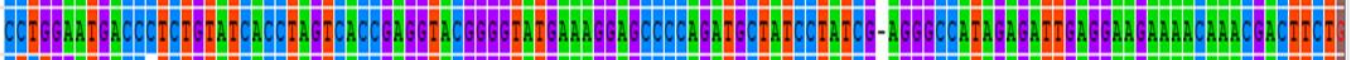 \\
\hline 4. 1_RR__Ele__Crossbred__attle & & 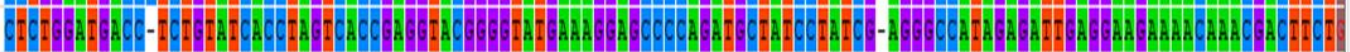 \\
\hline 5. 3. 3R__ERE_Crossbred_Catcle & & 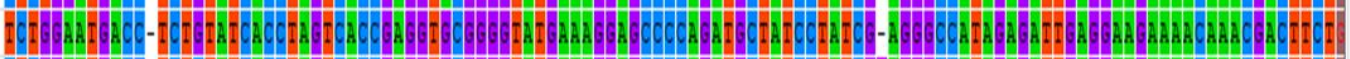 \\
\hline 6. 4_ER__GRE__Crossbred_attile & & 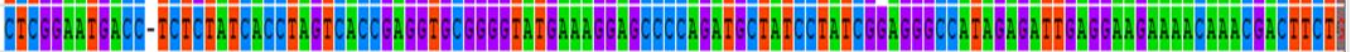 \\
\hline
\end{tabular}

Fig 5: Clustal w multiple alignment of partial sequences of PRL gene

\section{Discussion \\ Amplification PRL gene by PCR}

The amplification of PRL gene resulted in a product size of $156 \mathrm{bp}$ in all samples of crossbred cows used in the present study and was in good agreement with the results reported by Vermaet al. (2004) ${ }^{[10]}$ in crossbred cattle.

\section{PCR-RFLP analysis}

The conventional RFLP technique is very time consuming and laborious. Hence, in the present study PCR-RFLP technique was used to identify the genetic variants of PRL gene in crossbred cows. This technique was found to be simple and efficient in identifying the genetic variants of PRL genes.

Researchers earlier have already used the PCR-RFLP technique successfully to study the genetic variants of PRL gene in Cattle (Vermaet al., 2004) ${ }^{[10]}$.

\section{PCR-RFLP analysis of PRL gene}

Digestion of $156 \mathrm{bp}$ PCR products of PRL gene with Rsa I revealed three types of fragment pattern, arbitrarily designated as $\mathrm{AA}, \mathrm{AB}$ and $\mathrm{BB}$ genotypes. Following digestion of the PCR product, AA genotype yielded one fragment (156 bp), AB genotype yielded three fragments $(74,82$ and $156 \mathrm{bp})$ and BB genotype yielded two fragments (74 and $82 \mathrm{bp}$ ) in crossbred cows. This finding was in conformity with earlier observation of Verma et al. (2004) ${ }^{[11]}$ in crossbred cattle in India, Sodiet al. (2010) ${ }^{[10]}$ in Indian native breeds of cattle, Bukhari et al. (2013) ${ }^{[2]}$ in Sahiwal cattle, Sacravarty et al. (2008) ${ }^{[8]}$ in Kankrej Cattle in India and Patel et al. (2017) ${ }^{[7]}$ in Kankrej cattle. The gene and genotype frequencies of AA, $\mathrm{AB}$ and $\mathrm{BB}$ are shown in TABLE 4.

\section{Calculation of gene and genotype frequencies}

The allelic and genotypic frequencies were calculated as per the method described by Falconer and Mackay (1996) ${ }^{[4]}$. The frequencies of $\mathrm{A}$ and $\mathrm{B}$ alleles of PRL gene were 0.534 and 0.466; those of $\mathrm{AA}, \mathrm{AB}$ and $\mathrm{BB}$ genotypes were $0.334,0.400$ and 0.266 respectively.

The present findings revealed a higher frequency of $\mathrm{AB}$ genotype followed by AA and then by BB for PRL gene in crossbred cattle. These data were in conformity with findings reported by Sodi et al. (2010) ${ }^{[10]}$ who identified three genotypes $\mathrm{AA}, \mathrm{AB}$ and $\mathrm{BB}$ for $\mathrm{PRL}$ gene in Indian native cattle breeds; where the frequency of $\mathrm{AB}$ genotype was more compared to $\mathrm{AA}$ and $\mathrm{BB}$. However higher frequency of $\mathrm{AA}$ genotype followed by $\mathrm{AB}$ and then by $\mathrm{BB}$ for PRL gene were reported by Ghasemiet al. (2009) ${ }^{[5]}$ in Montebeliard cows, Sacravarty et al. (2008) ${ }^{[8]}$ in Knakrej cattle and Verma et al. (2004) ${ }^{[11]}$ in Jersey x HF x Sahiwal.

Association of different genotypes with various reproductive and productive traits

PRL- RFLP genotypes were found to have significant association with the age at sexual maturity $(P<0.05)$. The average age at sexual maturity (days) of crossbred cattle with $\mathrm{AA}, \mathrm{AB}$ and $\mathrm{BB}$ genotypes were found to be $908 \pm 36.81$, $868.17 \pm 11.38$ and $1252.25 \pm 55.57$ respectively.

Significant association with the age at first calving $(P<0.05)$ was found for PRL- RFLP genotypes. The average age at first calving (days) of crossbred cattle with $\mathrm{AA}, \mathrm{AB}$ and $\mathrm{BB}$ genotypes were found to be $1363.8 \pm 16.41,1244.5 \pm 10.32$ and $1661.75 \pm 13.71$ respectively. Crossbreds belonging to $\mathrm{AB}$ genotype were found to be high yielder than AA which was followed by crossbreds of BB genotype. These findings are in agreement with Sacravartyet al. (2008) ${ }^{[8]}$ in Kankrej cattle.

Significant association with first lactation milk yield $(P<0.05)$ was found for PRL- RFLP genotypes. The average first lactation milk yield $(\mathrm{kg})$ of crossbred cattle with $\mathrm{AA}, \mathrm{AB}$ and BB genotypes were found to be $1414 \pm 27.03,1603.83 \pm 55.93$ and $1107.25 \pm 157.89$ respectively. Crossbreds belonging to $\mathrm{AB}$ genotypes were found to have shorter age at first calving than AA genotypes which was followed by crossbreds of BB genotypes. These findings are in agreement with Vermaet al. (2004) ${ }^{[11]}$ in Jersey $\times$ HF $x$ Sahiwal.

Non-significant association with first lactation length $(P<0.05)$ was found for PRL- RFLP genotypes. The average first lactation length (days) of crossbred cattle with AA, AB and $\mathrm{BB}$ genotypes were found to be $278.6 \pm 17.94,312.17 \pm$ 14.54 and $262.25 \pm 29.25$ respectively. Crossbreds belonging to $\mathrm{AB}$ genotypes were found to have longer lactation length than AA genotypes which was followed by crossbreds of BB genotypes. These findings are in agreement with Vermaet al. (2004) ${ }^{[11]}$ in Jersey $\times \mathrm{HF} \times$ Sahiwal.

The observations with respect to association of different genotypes with various reproductive and productive traits revealed that the genotype $\mathrm{AB}$ is superior to AA genotype and $\mathrm{BB}$ genotype is least superior compared to the earlier ones. 


\section{Conclusion}

Effect of polymorphism in PRL gene with restriction enzyme $R s a \mathrm{I}$ was found for various production and reproduction traits in crossbred cattle maintained at Bull Mother Farm, Barapeta, Assam. This opens interesting prospects for future selective breeding programme, especially based on marker-assisted selection.

\section{Acknowledgments}

The authors thankfully acknowledge to Dr. A. Aziz, Professor and Head, Department of Animal Genetics and Breeding, College of Veterinary Science, Khanapara, Assam for his guidance and support to carry out this study.

\section{Disclosure statement}

No potential conflict of interest was reported by authors

\section{Funding}

This work was funded as M. V. Sc. research grant to the first author by the College of Veterinary Science, AAU, Khanapara, Ghy-22, Assam, India under the supervision of Department of Animal Genetics and Breeding, College of Veterinary Science, Khanapara, Assam, India.

\section{References}

1. Akyuz B, Agaoglu OK, Ertugrul O. Genetic polymorphism of kappa-casein, growth hormone and prolactin gene in Turkish native cattle breeds. International Journal of Dairy Technology. 2012; 65(1):38-44.

2. Bukhari S, Khan NN, Gupta P, Das AK, Raher GA, Chakraborty D et al. Prolactin gene polymorphism and its associations with milk production traits in Frieswal Cow.International Journal of Molecular Zoology. 2013; 3(3):10-13.

3. Dybus A, Grsesiak W, Kamieniecki H, Szatkowski I, Sobek Z, Blaszczyk $\mathrm{P}$ et al. Association of genetic variants of bovine prolactin with milk production traits of Black and White and Jersey cattle.Archiv for Tierzucht 2005;48:149-156.

4. Falconer DS, Mackay TFC. Introduction to Quantitative Genetics, $4^{\text {th }}$ Edition, Pearson Publication, 1996.

5. Ghasemi N, Zadehrahmani M, Rahimi G, Hafezian, S. Association between prolactin gene polymorphism and milk production in Montebeliard cows. International Journal of Genetics and Molecular Biology. 2009;1(3):48-51.

6. Livestock Census. Department of Animal Husbandry, Dairying \& Fisheries. Govt. of India,2012. (htttp://dahd.nic.in/document/statistics/livestock-census).

7. Patel JP, Chauhan JB. Polymorphism of prolactin gene and its relationship with milk production in Gir and Kankrej cattle. Journal of Natural Science, Biology and Medicine. 2017; 8:160-170.

8. Sacravarty G, Vadodaria VP, Joshi CG, Brahmkshtri BP, Shah RR, Solanki JV. Prolactin gene polymorphism and its association with economic traits in Kankrej cattle. IJDS. 2008; 61(4):273-276.

9. Sambrook JF, Russel DW. Molecular Cloning: A

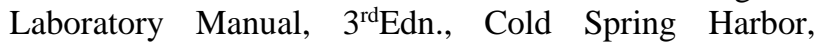
Laboratory Press, 2001.

10. Sodi M, Mukesh M, Mishra BP, Parvesh K, Joshi BK. Analysis of genetic variant at the Prolactin-RsaI (PRL$R s a \mathrm{I})$ locus in Indian native cattle breeds (Bosindicus). Biochemical Genetics. 2010; 49(1):39-45.
11. Verma P, Singh CV. Study of prolactin gene polymorphism in crossbred cattle of different genotypes to various traits. Genetic Improvement of Livestock and Poultry, 2004, 261-273. 